\title{
EC-LEDS
}

\section{DEVELOPMENT IMPACT ASSESSMENT (DIA) CASE STUDY: SOUTH AFRICA}

\author{
May 2015
}

Sadie Cox, Kathleen Nawaz, and Debra Sandor 


\section{ACKNOWLEDGMENTS}

The authors would like to thank Ron Benioff, Jeff Logan, Jessica Katz, and Kendra Palmer of NREL and Stephanie Bogle (USAID contractor) and Graham Paul (USAID/Southern Africa) for thoughtful review and input to the case study. 


\section{LIST OF ACRONYMS}

CDM clean development mechanism

CGE Computable General Equilibrium

DEAT Department of Environment and Tourism

DIA development impact assessment

EC-LEDS Enhancing Capacity for Low Emission Development

EGI Electricity Governance Initiative

ERC University of Cape Town Energy Research Center

FDI foreign direct investment

GDP gross domestic product

GHG greenhouse gas

GoSA Government of South Africa

IDRC International Development Research Center

I-O input-output

IRP Integrated Resource Plan

ISF Institute for Sustainable Futures

LEDS low emission development strategies

LTMS Long Term Mitigation Scenarios

MARKAL MARKet ALlocation model

MCA Multi-criteria analysis

NAMA Nationally Appropriate Mitigation Action

NCCRS National Climate Change Response Strategy

NDP National Development Plan

NGO non-governmental organization

OECD Organization for Economic Cooperation and Development

SBT "scenario building teams"

SNAPP Sustainable National Accessible Power Planning

SSN SouthSouthNorth

UNEP United Nations Environment Programme 


\section{TABLE OF CONTENTS}

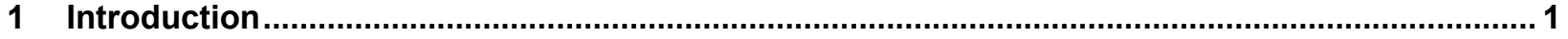

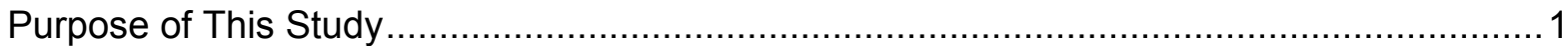

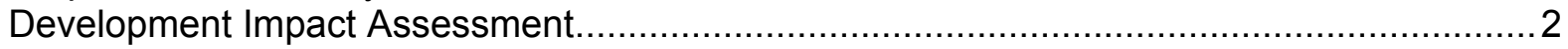

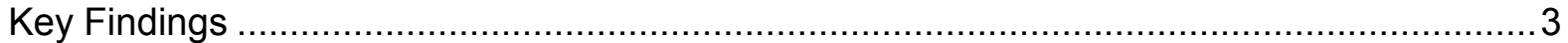

2 South Africa's Development Priorities and LEDS Processes................................................. 4

Long Term Mitigation Scenarios .................................................................................. 4

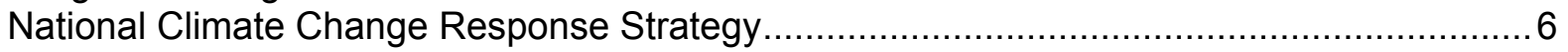

GoSA National Development Goals, NCCRS, and LTMS …..................................... 6

3 South Africa's Experience Assessing Development Impacts of LEDS Actions .......................... 7

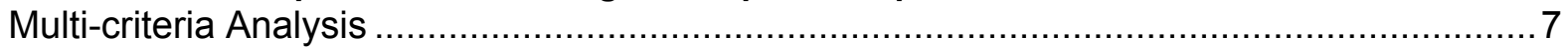

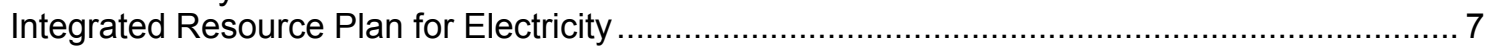

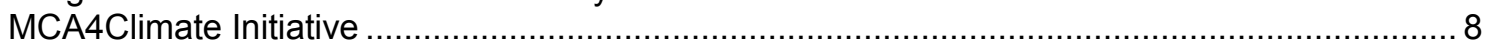

Lessons from Multi-criteria Impact Analyses in South Africa .............................................. 9

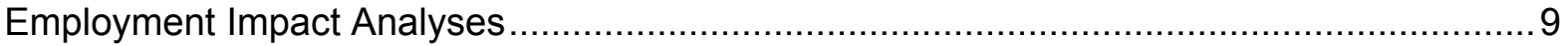

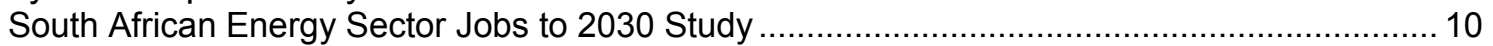

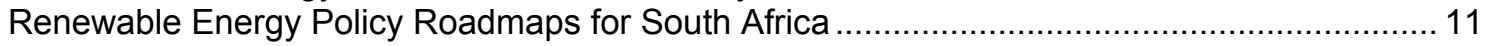

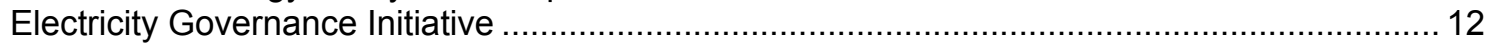

Lessons from Employment Impact Analyses in South Africa.............................................. 13

Water Use Impact Analysis .......................................................................... 13

A Review of Operational Water Consumption and Withdrawal Factors for Electricity

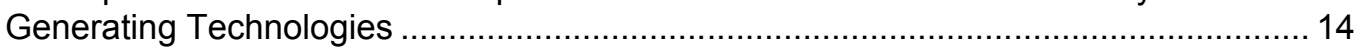

Energy, Water, and Climate Change in Southern Africa.......................................................... 14

Water Hungry Coal: Burning South Africa's Water to Produce Electricity ............................. 15

Water Scarcity and Electricity Generation in South Africa ...................................................... 15

Lessons from Water Use Impact Analyses in South Africa................................................... 16

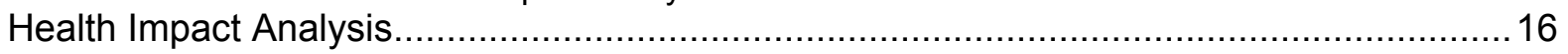

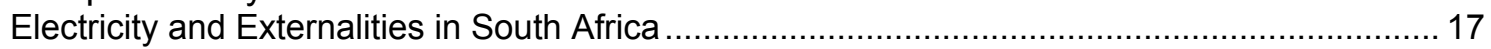

Kuyasa Clean Development Mechanism Project .............................................................. 17

Lessons from Health Impact Analyses in South Africa ....................................................... 18

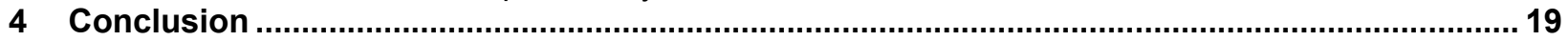

Value of DIA in Development and Implementation of LEDS in South Africa ............................. 20

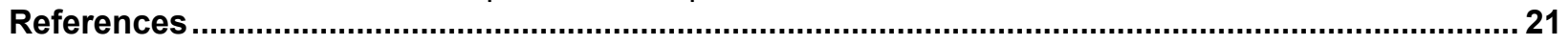

Appendix A. Illustrative Example of Analysis Integration to Support Prioritization of Low

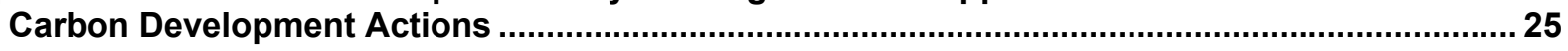

Appendix B. Summary Table of DIA Studies and Tools .............................................................. 29 


\section{LIST OF FIGURES}

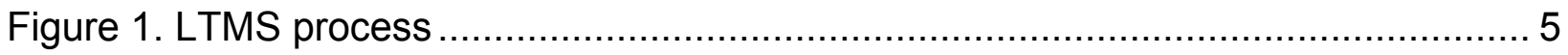

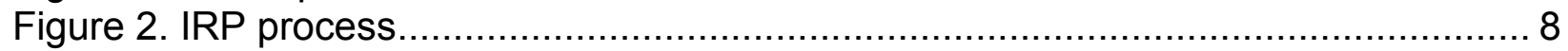

Figure 3. Electricity generation under ER, IEA, and GWC scenarios ........................ 11

Figure A-1. Sample DIA framework............................................................. 25

Figure A-2. Illustrative example of integrated DIA prioritization framework drawing from analysis presented in this case study .................................................. 26

\section{LIST OFTABLES}

Table 1. LTMS Economy-wide Modeling Outputs/Impacts by 2015 5

Table 2. GoSA Development Priorities and Key Low Carbon Development Activities Included in NCCRS and LTMS ........................................................ 6

Table 3. Gross Job Impact Assessment Calculations ............................................. 10

Table 4. Estimated Job Creation Impacts of Energy Technologies (2009) .................... 12

Table 5. EGI Smart Electricity Planning - Installed Capacity, Investment, and Job Creation Under Three Scenarios.......................................................... 13

Table 6. Median Water Consumption Factors for Select Electricity Generation Technologies ........................................................................... 14

Table 7. Water Consumption of Selected Energy Technologies ................................ 15

Table 8.Water Savings from Coal Power Substitution.............................................. 16

Table A-1. Scoring Scheme for Assessing Development Benefits of Clean Energy

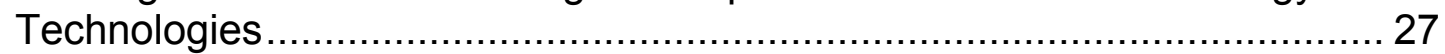

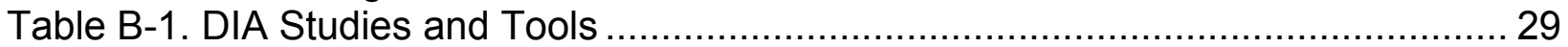




\section{Introduction}

Many nations face a dual challenge in achieving top priority national development goals-such as improving standards of living through increasing gross domestic product (GDP), extending access to modern energy, and increasing employment-while also supporting national climate change action. To support broader development goals while also reducing GHG emissions, a number of countries are developing and implementing low emission development strategies (LEDS)—which aim to achieve development priorities with minimal GHG emissions-as part of their national objectives. Historically, literature on evaluating impacts of a shift to a low emissions pathway has focused on costs (to GDP, for example), but in fact, the benefits may outweigh the costs when considering broader impacts (health, for example) (Scrieciu et al. 2014). In a series of case studies, the U.S. government's Enhancing Capacity for Low Emission Development Strategies (EC-LEDS) Program is helping to expand the global dialogue on the links between LEDS and development by documenting the experiences of EC-LEDS partner countries in assessing the impacts of greenhouse gas (GHG) mitigation technologies, policies, and programs upon national development priorities. The insights gained from these case studies can serve as a resource for analysts and decision makers around the world by providing examples of how peers have considered development impacts, both in terms of analytic approaches and methodologies, as well as results.

\section{Purpose of This Study}

South Africa is a regional and global leader in the climate change arena, and has produced a number of robust reports and proposed innovative actions to reduce GHG emissions and adapt to climate change. The electricity sector in South Africa is a key focus of these efforts as crucial electricity planning decisions are required to both meet development goals and address climate change priorities.

This case study reviews South Africa's experience in considering the impacts of climate change action on development goals, focusing on the South African energy sector and development impact assessments (DIAs) that have and could be used to influence energy policy or inform the selection of energy activities. It includes a review of assessments-conducted by government ministries, technical partners, and academic institutes and non-governmental organizations (NGOs) — that consider employment, health, and water implications of possible energy sector actions, as well as multi-criteria impact assessments. The study is intended to offer an example of one country's experience, and it summarizes:

- Possible impacts of low emission actions upon development priorities

- Approaches and methodologies used to conduct impact assessments

- Motivation for examining impacts and outcomes of the assessments.

Examining multiple analyses can illuminate LEDS actions under consideration, provide insights on common or contradictory DIA results needing further exploration, help to identify trade-offs among LEDS options with respect to their ability to meet development priorities, and support stakeholder dialogue and decision making in South Africa. Taken together, these assessments highlight numerous low emission development alternatives 
that have the potential to positively impact South Africa's development goals. However, the disparate scopes, methodologies, and results of these assessments, and their unclear impact on decision making at the national level, indicate the potential value of a holistic approach to assessing the development impacts of LEDS in South Africa. This case study also presents a broader framework and simple visual to integrate the various outputs of these analyses (both quantitative and qualitative) into an example prioritization structure in Appendix A. This simple structure is underpinned by credible analysis and aligned with topics of most interest to stakeholders, and it can help communicate these development impacts to the public and high level policy makers in order to gain the support needed to translate plans into action.

\section{Development Impact Assessment}

As countries develop and implement policies and programs to achieve development objectives, they can evaluate the impacts an initiative aimed at a key priority-such as supporting economic growth-may have on other priorities, such as energy access or GHG emissions. Although a priority of many countries (reflected in LEDS or otherwise), reducing GHG emissions is often secondary to primary economic and social objectives. Nonetheless, reducing GHG emissions impacts these primary objectives in ways and to a degree often not fully considered by decision makers. The web of interrelationships among development actions is complex, and DIAs ${ }^{1}$ can help to identify both positive and negative impacts in advance of implementing a policy, including understanding the type and extent of an impact, how a policy may impact different parts of the population, and the timeframe in which the impacts are likely to occur. Engaging in this analysis can also help present low emission development to a broader group of stakeholders to inform their decisions. In particular, communicating analysis results with stakeholders typically outside the "environmental" arena can help to broaden policy support and bridge understanding between groups that do not typically engage with one another.

For the purpose of this study, DIA is defined as a process for evaluating the likely economic, social, and/or environmental consequences of a LEDS action or set of actions within one or more development goals. Economic impacts may include GDP, foreign direct investment (FDI), employment/trade balance, and national security. Social impacts may include health (mortality and morbidity), poverty reduction, education, energy access, and gender equality. Environmental impacts may include GHG emissions, air quality, water availability and quality, climate resilience, and biodiversity. DIA aims to provide a rational and transparent approach to support decision making, and it also facilitates communication of priorities among stakeholders. It provides a framework for considering negative and positive effects of an action through application of data, models, analytic approaches, and experiences to anticipate outcomes. Our focus is on the national level, but DIA can also be applied at the local or community level to support decision making. Consideration of these factors and development impacts were included in reviewing available country analyses for South Africa.

\footnotetext{
${ }^{1}$ Although DIA is often referred to as "co-benefits analysis," that term is not used here for two reasons. First, impacts of an action may be negative as well as positive, and the broader term accounts for this possibility. (For example, increasing renewable power may decrease coal mining jobs). Second, the term has been used to assign a primary benefit to GHG reductions, with the co-benefits identified as all others-including economic growth, reduction in local pollutants, etc. The perspective in this paper places the country's development priorities as the primary benefit, with all others-including GHG reductions-as secondary benefits.
} 


\section{Key Findings}

South Africa is a leader in aligning climate change planning and action with the country's key development priorities. The Government of South Africa (GoSA) Long Term Mitigation Scenarios (LTMS) process presents a strong model of a stakeholderdriven, analytically robust approach to support inclusive and equitable low emission development. The iterative nature of robust stakeholder approaches, such as the LTMS, can be time-consuming; however, it is necessary to ensure plans are informed by multiple interests and will ultimately have the necessary support to move from planning stages to implementation.

According to the studies described in this paper, expanded production of electricity from renewables in South Africa could support job creation over the long term (with some differentiation among labor categories) and, as compared with coal, decrease water use and positively impact health in relation to air quality improvements. However, further data collection and development is needed to support more robust and improved analysis of job, water use, and health impacts; specific recommendations are noted herein. There may also be a need to support connection of analysis (such as the studies reviewed) with policy making through facilitating government engagement and dialogue with technical institutions, NGOs, and universities to ensure research findings are translated into action.

Integrating the results of the studies reviewed into a visual framework (see Appendix A) helps organize, communicate, and compare the development impacts of clean energy alternatives under consideration in South Africa. In practice, this framework can be used to present information on development impacts of possible mitigation actions, drawing from various analytical studies and with input from experts and stakeholders. The visual can then be used to compare possible mitigation actions in relation to development impacts of most interest to a country and ultimately, to communicate the development benefits of prioritized actions to policymakers and the public. Integrating and conveying the findings of analytical studies within the framework provides an accessible approach to summarize impacts to stakeholders. Coupled with an inclusive and transparent stakeholder process, the framework could be further adapted to provide a structure for development-focused prioritization of LEDS actions in South Africa. 


\section{South Africa's Development Priorities and LEDS Processes}

South Africa's National Development Plan (NDP) 2030 lays the foundation for LEDS actions and development more broadly in the country. The plan focuses on three key priorities: "1. Raising employment through faster economic growth, 2. Improving the quality of education, skills development and innovation, and 3 . Building the capability of the state to play a developmental, transformative role" (NPC 2012, pg. 17). In addition to these key priority areas, the NDP highlights climate change as an external driver with significant implications for development. To address climate change, the NDP proposes a number of actions including improved energy efficiency in the building sector, deployment of renewable energy technologies $(20,000 \mathrm{MW}$ by 2030), establishment of a carbon pricing mechanism, development of a Climate Change Center, improvement in preparation for natural disasters, and development of adaptation strategies, among others (NPC 2012).

Building on the objectives in the NDP, the LTMS and National Climate Change Response Strategy (NCCRS) have been influential in shaping low emission development action in South Africa. These documents, and the inclusive processes used to develop them, are discussed in greater detail below.

\section{Long Term Mitigation Scenarios}

In 2007, the GoSA's Department of Environmental Affairs and Tourism commissioned the University of Cape Town's Energy Research Center (ERC) to prepare a study titled Long Term Mitigation Scenarios (Winkler 2007). The LTMS process was mandated by the South African Cabinet and was largely driven by country stakeholders consisting of government staff, private sector and NGO representatives, experienced facilitators, ${ }^{2}$ and "Scenario Building Teams" (SBTs) with various technical experts contributing for each sector. According to the LTMS authors, the scenarios "are not so much future stories... but active options for future paths, seen against growth and emissions. Our scenarios [are] built on alternative dynamic paths that are based on key assumptions about the future and contain the actions required to achieve them" (Winkler 2007, pg. 9). The study was completed in approximately one year and fed into the NCCRS described below.

Stakeholders were engaged throughout the process to inform analysis assumptions and drivers and inputs, as well as to discuss outputs. The LTMS process is presented in Figure 1.

\footnotetext{
${ }^{2}$ Some of the LTMS facilitators were also engaged with post-Apartheid reconciliation efforts in South Africa and applied those lessons and skills to the LTMS process.
} 


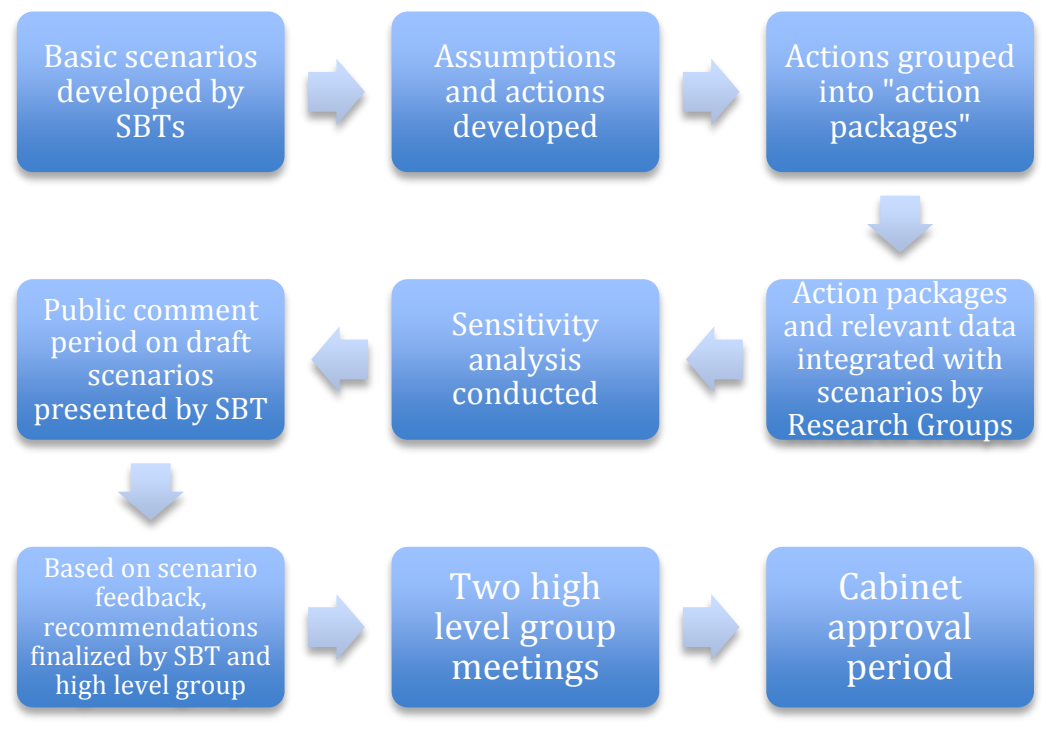

Figure 1. LTMS process

Source: Adapted from Winkler 2007

To inform the LTMS, various models and tools were used to assess sectoral and economy-wide mitigation options and impacts, including the MARKet ALlocation (MARKAL) model, input-output (I-O) multipliers, and computable general equilibrium (CGE) models. The use of these tools resulted in assessment of both GHG emission impacts and certain development impacts including GDP, employment, and poverty/welfare. Sensitivity analyses were also conducted in relation to GDP and energy prices, and for specific sets of actions (wedges). High level results of the economy-wide modeling effort that informed the LTMS are presented in Table 1.

Table 1. LTMS Economy-wide Modeling Outputs/Impacts by 2015

\begin{tabular}{|l|l|l|l|}
\hline Scenario and Key Actions & GDP & Employment & Poverty/Welfare \\
\hline $\begin{array}{l}\text { Industrial energy efficiency } \\
\text { Moderate changes in electricity } \\
\text { supply to renewables }\end{array}$ & $+0.2 \%$ & $\begin{array}{l}\text { Mixed: Positive for } \\
\text { unskilled, skilled, and } \\
\text { highly skilled (approx. } \\
1.3 \%), \text { but negative for } \\
\text { semi-skilled (-2\%) } \\
\begin{array}{l}\text { Transport shifts to more } \\
\text { efficient vehicles and public } \\
\text { transport }\end{array}\end{array}$ & $\begin{array}{l}\text { Positive for high income } \\
\text { households (hhs) and skilled } \\
\text { labor, but negative for low } \\
\text { skilled labor/poorer hhs }\end{array}$ \\
\hline $\begin{array}{l}\text { Zero carbon electricity by 2050 } \\
\text { with RE and nuclear, CCS, } \\
\text { biofuels, and electric vehicles }\end{array}$ & $+1 \%$ & $\begin{array}{l}\text { Positive for skilled and } \\
\text { highly skilled (+1\%) and } \\
\text { semi-skilled (+3\%) }\end{array}$ & $\begin{array}{l}\text { Positive for low skill labor } \\
\text { (esp. for biofuels); negative } \\
\text { for high income hhs }\end{array}$ \\
\hline $\begin{array}{l}\mathrm{CO}_{2} \text { tax } \\
\text { Source: Adapted figure from Winkler 2007 }\end{array}$ & $\begin{array}{l}\text { Mixed: Positive for semi- } \\
\text { skilled (+3\%), but negative } \\
\text { for skilled (-2\%) and highly } \\
\text { skilled (-4\%) }\end{array}$ & $\begin{array}{l}\text { Negative for all hhs except for } \\
\text { poor hhs that could gain from } \\
\text { subsidies initially }\end{array}$ \\
\hline
\end{tabular}

The results above demonstrate the complexity of gains and losses that could be experienced by different societal groups when governments pursue low carbon development actions. Another item of note is the near term focus of these particular modeling outputs (to 2015), which could change significantly over a longer timeframe. 


\section{National Climate Change Response Strategy}

South Africa's NCCRS builds on the results of the LTMS and provides the overall national policy framework for climate change mitigation and adaption actions. The strategy was developed through a consultative process with thematic workshops and open, online comment forums to refine the strategy from a green paper to a white paper. The white paper incorporates feedback from the consultations and topical research papers developed by sectoral experts from technical institutions and the government.

The NCCRS integrates both mitigation and adaptation actions/responses at the national level. Job creation is a key emphasis of the white paper; in fact, one chapter is solely focused on job creation. This strongly links the paper to the GoSA NDP that, as previously noted, highlights employment as one of the three high level development priorities for the country. A National Employment Vulnerability Assessment is planned to assess possible climate change impacts on jobs as well as sectoral job creation opportunities associated with climate change adaptation and mitigation. The white paper chapter on mitigation describes a plan to assess mitigation actions using a "carbon budget approach" ${ }^{3}$ and focuses on mitigation potential and job creation as two key prioritization factors. These actions will then feed into sectoral low carbon development strategies for the largest emitting sectors of the economy.

\section{GoSA National Development Goals, NCCRS, and LTMS}

The NCCRS and LTMS resulted in the proposal of a number of actions to reduce GHG emissions in a manner that aligns with South Africa's development goals. Some of these actions, which are being considered for Nationally Appropriate Mitigation Action (NAMA) proposals, are included below. Table 2 highlights the GoSA's development priorities as the framing objectives of LEDS activities in South Africa and aligns key LTMS actions with proposed NCCRS flagship programs.

Table 2. GoSA Development Priorities and Key Low Carbon Development Activities Included in NCCRS and LTMS

\begin{tabular}{|l|l|}
\hline \multicolumn{2}{|c|}{ GoSA Development Priorities } \\
\hline \multicolumn{2}{|c|}{ 1. Job creation through economic growth } \\
2. Enhanced education, development of skills, and innovation \\
\hline NCCRS White Paper Flagship Programs & LTMS Key Actions/Potential NAMAs \\
\hline Renewable Energy Flagship Program & $10 \mathrm{GW}$ of wind power up to 2020 \\
& 5 GW of CSP up to 2020 \\
\hline Energy Efficiency and Demand Management & Feed-in-tariffs for renewable energy \\
Flagship Program & Low income housing energy upgrades \\
\hline Transportation Flagship Program & Demand side management \\
\hline \multicolumn{1}{|c|}{ Source: "Presentation on NAMAs" 2013 } \\
\hline
\end{tabular}

As presented in the table above, the GoSA's development priorities provide framing for the LEDS actions that are being pursued in South Africa. In particular, the LTMS and NCCRS emphasize the need for actions to support the employment goals of the country. The following sections discuss analyses that have been undertaken to more closely link LEDS-related actions with the GoSA's development goals.

\footnotetext{
${ }^{3}$ Carbon budgets set a cap on the total amount of GHG emissions that can be emitted over a certain period of time.
} 


\section{South Africa's Experience Assessing Development Impacts of LEDS Actions}

Many DIAs have been conducted to understand the economic, environmental, and social impacts of proposed plans and policies to reduce emissions from the South African energy sector. Methodologies and results from select studies are summarized here, and for each category of impact analysis-multi-criteria, employment, water use, and health impact analysis-lessons learned are also provided.

\section{Multi-criteria Analysis}

Multi-criteria analysis (MCA) is a structured approach to decision making, considering both quantitative and qualitative factors. It can be defined as "any structured approach used to determine overall preferences among alternative options where the options accomplish several objectives. In MCA, desirable objectives are specified and corresponding attributes or indicators are identified.... MCA allows decision makers to include a full range of social, environmental, technical, economic, and financial criteria" (UNFCCC 2014). Various MCA tools and approaches have been applied to DIA in the South African energy sector, and two are discussed here.

\section{Integrated Resource Plan for Electricity}

To respond to competing needs in the energy sector (i.e., growing energy demand and desire to reduce $\mathrm{CO}_{2}$ emissions), the South African Department of Energy (DOE) developed an Integrated Resource Plan (IRP) presenting a scenario of new electricity supply from $2010-2030$ for development. ${ }^{4}$ While the principle driver of scenario choice was cost, other qualitative considerations, including development and climate impacts, were "balanced" through a multi-criteria decision making process. The IRP is intended to maximize national interest while meeting electricity demand at the least cost (Integrated Resource Plan 2014).

The IRP was developed using a data-intensive least cost optimization model to test various electricity supply scenarios. The model outcomes were then "balanced" with qualitative considerations. A working group of government departments designed a multi-criteria decision making process to consider the following impacts: cost (capital, operating, and fuel), GHG emissions, uncertainties associated with new technologies, local development, water use, and regional (Southern African) development. Cost, GHG emissions, water use, and regional development impacts were calculated using the optimization model while local development and uncertainty were assessed using qualitative methods (e.g., scores were assigned based on expected benefit or degree of uncertainty). To "balance" IRP scenarios in relation to the aforementioned impacts and further inform the analytical process, each scenario was given a score for GHG emissions, water use, local and regional development potential, etc. based on the analytical approaches noted above.

Inclusivity and transparency characterized the IRP development process as all stages were driven by input from stakeholders and scenario assumptions were revised (e.g.,

\footnotetext{
${ }^{4}$ The DOE has recommended the IRP for Cabinet adoption.
} 
disaggregation of technologies considered, revision of cost assumptions, etc.) based on various rounds of public consultation (Integrated Resource Plan 2014). The public consultation and iterative process to revise the IRP occurred over a 13-month period, as outlined in Figure 2.

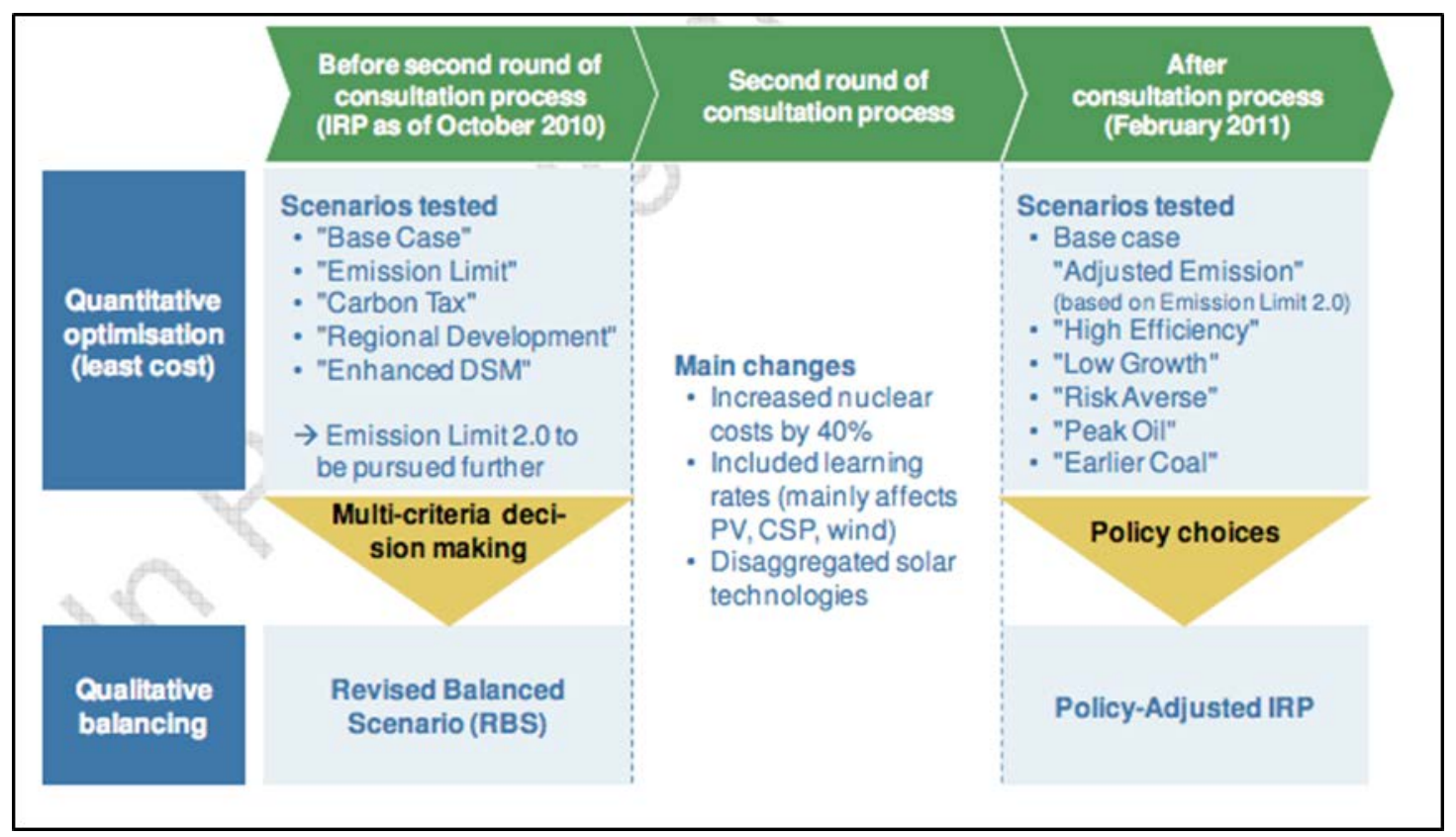

Figure 2. IRP process

Source: IRP 2011

The results of this process and related analysis led to the policy-adjusted IRP that includes the following actions:

- Increase in renewable installations (wind, photovoltaics [PV], and concentrated solar power [CSP]) to support local industry

- Nuclear development to address cost uncertainties related to fuels and renewable energy

- Reducing $\mathrm{CO}_{2}$ emissions to 210 million tons/year by 2050, as compared to approximately 430 million tons/year under a baseline scenario

- Implementation of energy efficiency demand side management actions.

The IRP incorporated a number of development indicators through use of a multi-criteria decision making process that considered local and regional development and water use impacts of various options, but feedback from public consultations highlighted the need for a more detailed socio-economic study of the IRP. A tender to conduct this study was released in 2012, but it is unclear whether the study has been completed.

\section{MCA4Climate Initiative}

Agama Energy ${ }^{5}$ and the University of Strathclyde, through the United Nations Environment Programme (UNEP) MCA4Climate Initiative, developed a case study

\footnotetext{
${ }^{5}$ Agama Energy is a renewable energy and energy efficiency consulting firm in South Africa.
} 
documenting how analytical results from the IRP scenario development process could feed into a broader and more "dynamic and transparent" MCA of electricity options in South Africa. The case study also drew analytical outputs from the White Paper on Renewable Energy Policy developed by the South African DOE (White Paper on Renewable Energy 2003). Impact criteria considered under the IRP process (cost, GHG emissions, uncertainties associated with new technologies, local development, water use, and regional development) were adapted to be included within the MCA4Climate framework. For three of the impacts, modeling outputs were used to adapt the scores while three other impacts required expert judgment for scoring and ranking. The team then weighted different criteria that might reflect the priorities of decision makers and stakeholders in South Africa (e.g., public financing needs, implementation barriers, policy effectiveness, etc.) and finally aggregated scores and weights to assess different electricity policy options. The study noted that the weights assigned were merely illustrative given that the process did not involve actual engagement of South African decision makers and other stakeholders.

The MCA4Climate case study did not involve a stakeholder process, but was instead intended to illustrate how the tool could be used through a more inclusive and government-led process in South Africa. The case study demonstrates the value of incorporating outputs from related analytical processes that have already been undertaken to inform these types of efforts. However, as noted, a more robust, stakeholder-led use of the tool and process would be necessary to inform policymaking (Morris and Belton 2011).

\section{Lessons from Multi-criteria Impact Analyses in South Africa}

- Inclusive and transparent stakeholder approaches are needed to support multicriteria impact assessment. The iterative nature of these approaches can be time-consuming, but is necessary to ensure plans are informed by multiple interests and will have the necessary support to move from planning stages to implementation.

- When analyzing possible low carbon development actions, gains and losses that could be experienced by various societal groups must be considered to ensure equitable actions and policies are pursued.

- Drawing from available country data and analysis can be a useful and efficient approach to inform multi-criteria impact assessment; however, these approaches must be coupled with stakeholder processes that ensure the analysis is presented transparently through discussions with experts and practitioners. In particular, weighting of criteria (by outside experts) can have a significant impact on analytical results, further highlighting the need for stakeholder input to ensure transparency and verify findings.

\section{Employment Impact Analyses}

Jobs are a critical concern to the GoSA. Its Department of Environmental Affairs specifically notes job creation as an area that should be aligned with climate change mitigation policies, activities, and approaches (National Climate Change Response White Paper n.d.). A number of studies have been conducted analyzing job impacts of possible low carbon activities in the South African electricity sector. 


\section{South African Energy Sector Jobs to 2030 Study}

The Institute for Sustainable Futures (ISF) produced the South African Energy Sector Jobs to 2030 study in 2010, which was published by Greenpeace Africa and peer reviewed by the ERC. The analysis used electricity consumption projections and job multipliers to develop three "green job" scenarios for South Africa in 2010, 2020, and 2030 (Rutovitz 2010). Employment projections were calculated with the following inputs: projected electricity generation and installed capacity, local employment factors. ${ }^{6}$ Table 3 describes calculations used to estimate gross job impacts across technologies. ${ }^{7}$

Table 3. Gross Job Impact Assessment Calculations

\begin{tabular}{|l|}
\hline $\begin{array}{l}\text { Gross Jobs = Manufacturing + Construction + Fuel supply + O\&M + Coal export * Technology } \\
\text { decline factor }\end{array}$ \\
\hline $\begin{array}{l}\text { Manufacturing gross jobs = MW installed/yr (or exported) }{ }^{*} \text { manufacturing employment factor } \\
\% \text { local manufacturing }\end{array}$ \\
\hline Construction gross jobs = MW installed/yr * construction employment factor \\
\hline O\&M gross jobs = capacity ${ }^{*}$ O\&M employment factor \\
\hline Fuel supply gross jobs = electricity generation * fuel employment factor \\
\hline Coal export gross jobs = coal export tons * fuel employment factor \\
\hline
\end{tabular}

Source: Adapted from Rutovitz 2010

The study notes limitations associated with data, including the use of OECD data where local employment factors were not available. The author also noted that employment outputs from the study are only indicative given the many assumptions used to make calculations (some are noted above). Sensitivity analyses were performed to assess the relationship between inputs and possible output uncertainties (e.g., for regional employment factors).

ISF found that the "Energy Revolution" (ER) scenario, which incorporated the greatest amount of renewable electricity and energy efficiency technologies, supported the most jobs by 2030, as compared to the "IEA Reference case" and the "Growth Without Constraints (GWC)" scenario. Figure 3 presents the electricity generation assumptions under each scenario considered.

\footnotetext{
${ }^{6}$ Local factors were only available for mining, O\&M, and construction for coal, O\&M for nuclear and hydro, and all stages of employment for solar water heaters), regional employment factors from the Organization for Economic Cooperation and Development (OECD) (for all other technologies, adjusted to account for greater labor intensity levels), learning adjustment rates (to account for reductions in employment as technologies advance), local manufacturing data, projected regional coal and renewable energy exports, and OECD data to estimate employment associated with energy efficiency.

${ }^{7}$ Impacts are gross as opposed to net. Gross impacts do not consider a wide range of potential corollary impacts such as displaced economic activity or price changes.
} 


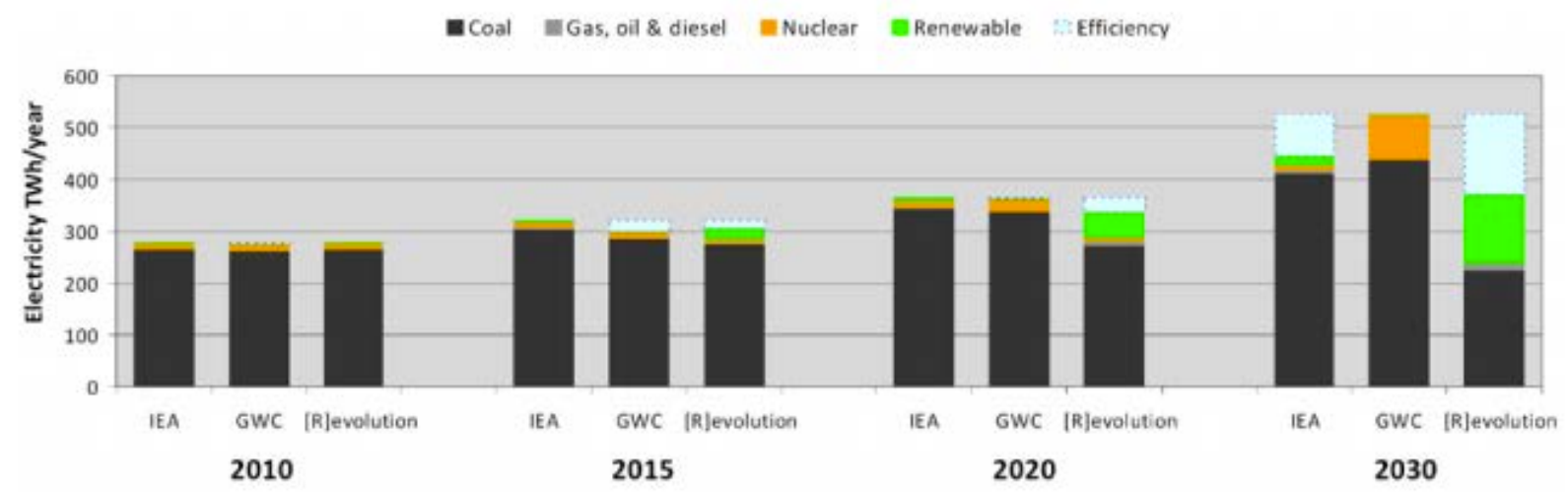

Figure 3. Electricity generation under ER, IEA, and GWC scenarios

Source: Rutovitz 2010

According to the study, the ER scenario produced 78,000 jobs by 2030 while also reducing GHG emissions by $60 \%$ by 2050 . This study and its reference scenario were updated in 2011 to reflect the IRP (Gets and Mhlanga 2013). Jobs supported by the ER scenario were still estimated to be significantly greater than the updated IRP reference scenario. It is unclear whether this study was/will be used by the GoSA to inform policy decisions.

\section{Renewable Energy Policy Roadmaps for South Africa}

ERC, with funding from UNEP, developed Renewable Energy Policy Roadmaps for South Africa using the Sustainable National Accessible Power Planning (SNAPP) Tool. SNAPP, developed by ERC and WWF-South Africa, is a spreadsheet-based electricity planning tool that can be used to develop simple electricity scenarios or more detailed technical analyses.

To inform the employment assessment for the roadmaps, ERC reviewed relevant literature to estimate job impacts of various electricity generating technologies. Table 4 presents the literature review findings that estimate gross jobs/MW for the construction, manufacture and installation, and O\&M and fuel processing stages of electricity generation projects (Austin et al. 2003). Based on this assessment of available literature, the study finds that renewable energy technologies can often support greater gross job creation than coal, open cycle gas turbine, and nuclear technologies, at least in the construction and installation phases. 
Table 4. Estimated Job Creation Impacts of Energy Technologies (2009)

\begin{tabular}{|c|c|c|c|}
\hline Technology & $\begin{array}{c}\text { Construction, manufacture, } \\
\text { and installation jobs (per } \\
\text { MW) }\end{array}$ & $\begin{array}{c}\text { O\&M and fuel } \\
\text { processing } \\
\text { jobs (per MW) }\end{array}$ & Relevant studies \\
\hline Coal (existing) & 0 & 0.75 & $\begin{array}{c}\text { South Africa DoE, 2009 } \\
\text { and ESKOM, 2009 }\end{array}$ \\
\hline Coal (super critical) & 2.5 & 0.65 & $\begin{array}{c}\text { Agama Energy, 2003 } \\
\text { and ESKOM, 2009 }\end{array}$ \\
\hline Open cycle gas turbine & 3.4 & 0.17 & $\begin{array}{c}\text { Rutovitz and Atherton, } \\
2009\end{array}$ \\
\hline Nuclear & 1.8 & 0.68 & $\begin{array}{c}\text { Rutovitz and Atherton, } \\
2009\end{array}$ \\
\hline Biomass & 8.5 & 14 & $\begin{array}{c}\text { Working for Energy, } \\
2009 \text { and Kammen, } \\
2004\end{array}$ \\
\hline Landfill gas & 15 & 2.3 & Agama Energy, 2003 \\
\hline Wind & 3.8 & 1 & $\begin{array}{c}\text { Agama Energy 2003 and } \\
\text { EWEA, 2009 }\end{array}$ \\
\hline Concentrated solar power & 10 & 0.4 & $\begin{array}{c}\text { GPI and ESTELA, 2009 } \\
\text { and NREL, 2006 }\end{array}$ \\
\hline Solar photovoltaic & 30 & 0.4 & Agama Energy, 2003 \\
\hline Solar water heaters & 21 & 0 & \\
\hline
\end{tabular}

Source: Adapted from Edkins, Marquard, and Winkler 2010

\section{Electricity Governance Initiative}

The Electricity Governance Initiative (EGI), a consortium of civil society institutions supported by the World Resources Institute, produced a Smart Electricity Planning document that also uses the SNAPP spreadsheet tool to present an alternative electricity plan for South Africa (Abrahams et al. 2013). Using the IRP (2011) described above as a baseline scenario, the EGI proposes alternative electricity scenarios that are more heavily focused on renewables and energy efficiency and that emphasize "propoor smart electricity planning." Notably, the scenarios consider multiple criteria to assess energy supply options such as energy access, gender, health and welfare, quality of life, and biodiversity impacts and also consider policies such as lower electricity tariffs and subsidies for lower income groups of the population to support "pro-poor" electricity supply. The study found that the scenario focusing heavily on renewable energy and energy efficiency would add significantly more gross jobs in 2050 and require less investment (Table 5). One primary reason for the lower investment costs relates to the high costs of nuclear that would be replaced with RE in the "Smart Scenarios" ("Smart Electricity" n.d.). 
Table 5. EGI Smart Electricity Planning - Installed Capacity, Investment, and Job Creation Under Three Scenarios

\begin{tabular}{|c|c|c|c|}
\hline & IRP (2010) - baseline & Smart Scenario 1 & Smart Scenario 2 \\
\hline & \multicolumn{3}{|c|}{ Contribution to total installed capacity (\%) } \\
\hline $\begin{array}{l}\text { Renewables (including } \\
\text { hydro and pumped } \\
\text { storage) - } 2030\end{array}$ & $37 \%$ & $67 \%$ & $74 \%$ \\
\hline Coal - 2030 & $27 \%$ & $20 \%$ & $18 \%$ \\
\hline Nuclear - 2030 & $18 \%$ & $0 \%$ & $0 \%$ \\
\hline $\begin{array}{l}\text { Open cycle gas turbine - } \\
2030\end{array}$ & $9 \%$ & $2 \%$ & $2 \%$ \\
\hline $\begin{array}{c}\text { Combined cycle gas } \\
\text { turbine }-2030\end{array}$ & $4 \%$ & $5 \%$ & $0 \%$ \\
\hline Investment $^{8}$ & R910bn & R692bn & R729bn \\
\hline 2020 Job Creation & Approx. 15,000 & $\mathrm{~N} / \mathrm{A}$ & Approx. 15,000 \\
\hline 2030 Job Creation & Approx. 35,000 & $\mathrm{N} / \mathrm{A}$ & Approx. 55,000 \\
\hline
\end{tabular}

Source: Adapted from Abrahams et al. 2013

\section{Lessons from Employment Impact Analyses in South Africa}

- Development and climate strategies in South Africa emphasize the need for expanded job creation through further development of competitive industries and sectors. Available analyses, described above, can be leveraged to inform electricity sector decisions that maximize job creation impacts.

- The three studies reviewed find that investment in renewable electricity technologies could add more jobs than investment in traditional technologies (e.g., coal, natural gas, and nuclear).

- However, these studies estimate gross job impacts and not net jobs, and therefore likely overstate increased jobs since trade-offs or job impacts associated with replaced technologies are not considered in the studies above. There may be a need for further assessment of job "replacement" impacts for various electricity technology portfolios.

- The studies used international data and assumptions for some energy technologies since data specific to South Africa was not available. Further work could be pursued to develop local employment factors for South Africa and non-OECD countries to support more rigorous assessment of job impacts of low carbon electricity options in South Africa and other developing countries.

- It is unclear whether the jobs studies reviewed have played a significant role in informing policy decisions in South Africa. Further research is needed to determine how available job impact analyses are being utilized to inform decision making.

\section{Water Use Impact Analysis}

Water scarcity is an increasing concern in South Africa, which is currently the 29th driest country in the world (Muller 2012). Rainfall varies significantly across seasons. Much of the water demand is also in urban centers that are not located near fresh water

\footnotetext{
${ }^{8}$ Using 2010 solar PV costs.
} 
sources. ${ }^{9}$ Climate change is also contributing to the water scarcity problem and hydroelectric dams have seen decreasing water levels in recent years (The Water Project 2014). Four studies on water consumption for electricity generation in South Africa are discussed here.

\section{A Review of Operational Water Consumption and Withdrawal Factors for Electricity Generating Technologies}

Macknick et al. (2011) assessed water consumption and withdrawal for the operational phase of electricity generating technologies using data for power plants in the United States collected by the EIA, USGS, state utilities, and a number of other international sources (listed in the references section). The study did not consider geographic location or climatic conditions for power plants, and also noted limitations related to data collection from multiple sources (e.g., lack of common definitions, methodologies, etc.). Table 6 shows median operational water consumption factors (gallons/MWh) and information sources for select electricity generating technologies considered in this study (Macknick et al. 2011).

Table 6. Median Water Consumption Factors for Select Electricity Generation Technologies

\begin{tabular}{|l|c|}
\hline \multicolumn{1}{|c|}{ Technology } & $\begin{array}{c}\text { Median Water Consumption Factor } \\
\text { (gallons/MWh) }\end{array}$ \\
\hline Wind Turbine & 26 \\
\hline Utility Scale PV & 0 \\
\hline CSP (Tower Trough) & 865 \\
\hline Coal (Tower Generic) & 687 \\
\hline
\end{tabular}

Source: Macknick et al. 2011

\section{Energy, Water, and Climate Change in Southern Africa}

The ERC was commissioned by the International Development Research Center (IDRC) to undertake a study on the water-energy-climate change nexus in Southern Africa. The study (Prasad et al. n.d.), focusing on four countries in the region, looked at efforts to integrate water and energy planning in the context of climate change, rural water service opportunities, water-energy policies in South Africa, and specific adaptation technologies.

Referencing electricity technology water consumption data from Macknick et al. (2011) (summarized in Table 6), the study notes that PV, dish sterling CSP, and wind technologies require little water to produce electricity as cooling is not required and only a minimal amount of water is used for cleaning purposes (for PV). CSP trough and Fresnel technologies are estimated to use up to 1,000 gallons of water/MWh for cooling while other thermal technologies are estimated to have greater water consumption needs (Macknick et al. 2011). For CSP, biopower, and natural gas combined cycle thermal technologies, water consumption is an order of magnitude less than for recirculating cooling at each of those types of plants (Macknick et al. 2011).

\footnotetext{
${ }^{9}$ This is true because many urban centers were developed near mining centers, which were often not close to water sources.
} 
The study noted that while the GoSA has developed the IRP, more effort could be made to integrate water considerations. IDRC presented the following approach for integrating water considerations with broader electricity plans:

- Identify available data and data gaps; possibly use expert judgment where data gaps exist

- Construct various scenarios that consider possible problem areas, goals at the regional and national levels, possible future policies, economic conditions, and climate change

- Develop energy-water-climate nexus model(s) in consultation with stakeholders to consider policy options, critical areas for action, sub-national and rural needs, and social development goals and priorities

- Analyze model runs to identify areas for action, magnitude of water, energy and climate change cross-effects, local actions that can have a large impact, and data sensitivities

- Refine and possibly expand model to further assess impacts of local/community action (Prasad et al. n.d.).

\section{Water Hungry Coal: Burning South Africa's Water to Produce Electricity}

A report funded by Greenpeace, Steele and Shulz (2012) builds on the Greenpeace job study described above to estimate water usage of the aforementioned energy scenarios. The study found that the ER scenario used significantly less water than the reference case. To inform these scenarios, Greenpeace estimated water consumption of coal, CSP, and wind power in the South African context. The findings are included in Table 7 and are consistent with the figures informed by international data in Macknick et al. (2011) (Steele and Shulz 2012).

Table 7. Water Consumption of Selected Energy Technologies

\begin{tabular}{|l|c|}
\hline \multicolumn{1}{|c|}{ Technology } & Water Consumption (gallons/MWh) \\
\hline Coal-fired power plant (dry cooling) & 174 \\
\hline Parabolic trough CSP (dry cooling) & 78 \\
\hline Wind & 1 \\
\hline
\end{tabular}

Source: Adapted from Steele and Shulz 2012 and Blignaut et al. 2011

\section{Water Scarcity and Electricity Generation in South Africa}

Wassung (2010) assessed the water use impacts of coal-fired power plants as compared to RE technologies. Similar to other international assessments, the author concluded that RE technologies such as wind, tidal and wave energy, solar PV, and parabolic dish CSP are significantly less water-intensive. In the context of South Africa, Wassung estimated water savings from replacing coal power generation with renewable generation using technology-specific water factors. Findings are presented in Table 8. 
Table 8. Water Savings from Coal Power Substitution

\begin{tabular}{|l|c|}
\hline \multicolumn{1}{|c|}{ Coal Power Substitute } & Water Savings (gallons/MWh) \\
\hline Wind, tidal, wave & 879 \\
\hline PV & 842 \\
\hline CSP (dish sterling) & 842 \\
\hline CSP (trough, central tower receiver) & $102-139$ \\
\hline
\end{tabular}

Source: Adapted from Wassung 2010

Note: Water consumption for coal power is estimated at 879 gallons/MWh.

\section{Lessons from Water Use Impact Analyses in South Africa}

- Water scarcity is a significant challenge in South Africa that is expected to worsen with climate change. Available analyses, described above, can be leveraged to inform electricity sector decisions that minimize water consumption impacts.

- Recent expansion of the South African electricity sector has focused largely on coal and nuclear power. The four studies described above find that most renewable electricity technologies (with the exception of trough CSP) require less water consumption than coal-fired and nuclear power plants. Water consumption for coal and nuclear power plants depends on the cooling technology employed (Macknick et al. 2011).

- More robust analytical approaches may be needed to further support holistic policymaking to address water-energy-climate challenges. These include:

- Further local data collection to better represent geographic location, climatic conditions, water consumption, and withdrawal data for South African power plants as well as development of country-specific water consumption factors for electricity technologies

- Development of common water use data collection methodologies and reporting conventions by power plants to ensure consistency for analytical purposes

- Further assessment of sub-national/regional water constraints and opportunities

- Development of country-specific models to assess the opportunities and trade-offs related to energy, water, and climate at the national and subnational levels.

- It is unclear whether the water use studies reviewed have played a significant role in informing policy decisions in South Africa. Further research is needed to determine how available water use impact analyses are being utilized to inform decision making.

\section{Health Impact Analysis}

Public health is a key development priority for many countries around the world. While much of the health discussion in South Africa has focused on HIV and AIDS (Chopra et al. 2009), there is also growing interest in addressing air quality (indoor and outdoor) related health issues ("Quick Best Practices Guide" 2012) as well as further health issues associated with heat fuel use in low income/rural areas. The studies summarized here investigate health impacts associated with different electricity technology options, 
as well as evidence from case studies relating to health impacts of energy efficiency projects in low-income areas.

\section{Electricity and Externalities in South Africa}

Spalding-Fecher and Matibe (2003) evaluated health externalities of air pollution from electricity production in South Africa. To perform the analysis, the authors used mortality and morbidity valuations and the EXMOD model, developed in the United States by the Tellus Institute. EXMOD is an impact pathway model for assessing links between emissions and human health, ultimately providing a valuation for human health impact. The authors note that the mortality methodology is drawn from international studies (primarily from developed countries) using "benefits transfer," which has been cited as a controversial method that can lead to analytical uncertainties. ${ }^{10}$ Other data limitations included the lack of information on municipality owned coal-fired power plants and general scarcity of plant-specific data. A recent Greenpeace study estimates the health costs of electricity from coal in Kusile, South Africa at $0.006-0.007$ Rand/kWh (or $\$ 0.00049-0.00057 \mathrm{USD} / \mathrm{kWh}$ ) (The True Cost of Coal n.d.). Extrapolating that cost to all of South Africa, which produced 184 billion KWh of electricity from coal in 2012, ${ }^{11}$ health costs are estimated at $\$ 90-\$ 105$ million USD.

\section{Kuyasa Clean Development Mechanism Project}

A clean development mechanism (CDM) project ${ }^{12}$ to retrofit 2,300 low income housing in Kuyasa with energy efficient technologies-solar hot water heaters (SWHs), energy efficiency lighting, and roof insulation-was registered by SouthSouthNorth (SSN) and funded for implementation by the Department of Environment and Tourism's (DEAT) Social Responsibility Program and Provincial Government's Department of Housing in 2008 (Goldman 2010). Initially, SSN piloted the project with 10 homes in 2005. This was South Africa's first CDM project and the first project to be registered as Gold Standard. These projects are considered to be of the highest quality due to their analytical robustness and low carbon development benefits (Gold Standard Foundation 2014).

Since implementation, in addition to reducing $\mathrm{GHG}$ emissions by $6,580 \mathrm{tCO}_{2}$ eq/year, the Kuyasa CDM Project has demonstrated development impacts-social (including health), economic, and empowerment-in the community. Development impacts of the project were assessed based on community responses to a baseline survey in 2008 and an impact survey circulated one year after implementation of the project in 2009. Initial analysis from the survey found that the majority of respondents have benefitted through reduced spending on electricity, reduced spending on fuel for heating (paraffin), reduced respiratory illness related to paraffin fumes and roof condensation, improved safety from reduced open fuel burning, and improved thermal comfort, and improved quality of life ("Project 0079" n.d.). Communities in Cape Town, including Kuyasa, experience high incidences of tuberculosis, chronic bronchitis, and asthma, in part due

\footnotetext{
${ }^{10}$ Valuation measures for "loss of life" can differ by country and region; see Spalding-Fletcher and Matibe (2003), p. 723.

${ }^{11}$ Assumptions used in estimate: Health costs (for Kusile only) $=182-213$ million Rand (based on $32301 \mathrm{GWh}$ coal generation (The True Cost of Coal n.d.) which estimates the 1 ZAR (Rand) $=0.0869$ USD (Bloomberg 2015). In 2012, 238.95 billion kWH of electricity production total (IEA n.d.) $77 \%$ of power from coal in South Africa ("Coal Power" 2015).

${ }^{12}$ CDMs are cooperative mechanisms (established under the Kyoto Protocol) designed to help developing countries achieve sustainable development and help industrialized countries their GHG emission reduction commitments.
} 
to burning paraffin and damp and cold housing conditions. Improved housing can contribute to reducing these respiratory conditions (CDM Videos 2014). Results of the household surveys completed for the Kuyasa CDM Project showed a $76 \%$ reduction in the incidence of respiratory illness as a result of warmer, drier homes in winter (UNFCCC 2010). The project illustrates how the CDM can help to improve health and quality of life for people in low-income urban communities. Demonstration of this project and associated impacts can now be used to inform assessment of possible

development impacts of similar projects that could be implemented in South Africa.

\section{Lessons from Health Impact Analyses in South Africa}

- The two studies reviewed find that investment in renewable electricity and energy efficiency technologies could reduce negative health effects associated with air quality impacts of coal-fired power plants as well as indoor air quality and safety issues related to traditional fuels.

- In regard to analysis of health impacts of electricity technologies, there may be a need for updated studies (as the study cited is from 2003) and/or further research to identify more recent available studies.

- Expanded data collection efforts could also help to improve health impact analysis (e.g., collection of South African coal-fired power plant-specific data to replace international data).

- The Kuyasa CDM Project presents a strong example of actual health impacts on the ground. Further collection of demonstrated impact data through surveys and interviews of residents (in the case of energy efficiency) and project implementers could help to corroborate and improve the robustness and reliability of impact analysis of energy projects.

- It is unclear whether the health studies reviewed have played a significant role in informing policy decisions in South Africa. Further research is needed to determine how available health impact analyses are being utilized to inform decision making.

Overall, the research seems to indicate that preferential development of renewable electricity can support the GoSA's drive to address unemployment, reduce water use and health impacts of coal generation, and at the same time, support the government's climate change objectives. It is unclear how the results of these past development impact analyses have been used to inform decision making, but in the context of low carbon development, employment, water use, and health impacts will all likely be of great interest to stakeholders and policymakers when comparing technologies. 


\section{Conclusion}

Government organizations and technical institutes have conducted analyses to explore the relationships between low emissions development and overall national development goals. The GoSA's development priorities include economic goals such as employment as well as climate change goals. The relationships between these goals are complex, and studies conducted in South Africa indicate that a growth trajectory with a greater emphasis on renewables in the electricity sector may, in fact, support key development objectives. These include increased employment-at least in the construction phase, reduced water consumption, and improved health impacts from lower emissions, all compared with coal power.

More specifically, the studies find:

- Consideration of broader impacts suggests significant benefits from a more diversified electricity supply. Government and technical institutions in South Africa have used multi-criteria impact assessment approaches to inform prioritization of sectoral and economy-wide activities that align with the development and climate goals of the country. The government-led IRP for Electricity aimed at considering the trade-offs between meeting growing energy demand and a commitment to reducing GHG emissions. It led to a policy-adjusted IRP that recommended increased renewables, nuclear power development, implementation of energy efficiency measures, and reducing $\mathrm{CO}_{2}$ emissions. The MCA4Climate study also pointed to benefits related to regional development and consumption from scaling up RE deployment.

- Stakeholder engagement is critical in assessing development impacts. Inclusive and transparent stakeholder approaches are necessary to support multi-criteria impact assessment. The iterative nature of these approaches can be time-consuming, but is necessary to ensure plans are informed by multiple interests and will ultimately have the necessary support to move from planning stages to implementation. Drawing from available country data and analysis can be a useful and efficient approach to inform multi-criteria impact assessment; however, these approaches must be coupled with stakeholder processes to ensure the analysis is presented transparently through discussions with experts and practitioners. In particular, weighting of criteria (by outside experts) can have a significant impact on analytical results, further highlighting the need for stakeholder input to ensure transparency and verify findings.

- An integrated DIA framework can facilitate decision making that supports carbon mitigation and national development priorities. Bringing together the DIA analyses referenced in this study under an integrated DIA framework can support decision making that reflects a broad set of possible impacts and ultimately produces wider benefits and more positive outcomes across multiple sectors of the economy and a broader set of stakeholders. Such a tool can be invaluable in providing a clear and concise summary of likely development impacts of low emission development actions.

The studies considered in this paper also highlight some limitations associated with specific analysis and DIA more broadly. Possible future circumstances, uncertainty, 
intergenerational equity issues, non-market impacts, and irreversibility of certain actions are all significant and complex considerations, and are often difficult to appropriately reflect, measure, and communicate through DIA. Some studies also described the need for more detailed analysis of development impacts, such as the IRP. While the studies considered in this paper do have limitations, they help to shed significant light on impacts of electricity sector actions, beyond simple consideration of costs and benefits.

Overall, the findings illustrate a number of positive impacts associated with low carbon electricity actions that align with key GoSA development priorities. However, it is unclear whether the studies reviewed have played a significant role in informing policy decisions in South Africa. Supporting further connection of analytical activities with policymaking through facilitating government engagement and dialogue with technical institutions, NGOs, and universities could help to inform decision making and ensure research is translated to action.

\section{Value of DIA in Development and Implementation of LEDS in South Africa}

South Africa's national development priorities, most notably job creation, are closely linked with potential LEDS activities in the country. This case study described a number of interesting examples of DIAs focused not only on jobs, but other development impacts that align well with South Africa's development priorities and national circumstances. These studies were integrated into an overarching framework, which demonstrates the value of summarizing available information and analysis to inform development-focused prioritization of LEDS technologies. The framework can be readily expanded to include consideration of other impacts. It can also easily incorporate weighting of impacts to reflect stakeholder priorities. Such a tool can be invaluable in providing a concise, transparent summary of likely impacts of LEDS actions. As the GoSA moves forward in addressing challenges, such as meeting power needs and creating employment, it has the opportunity to make decisions that reflect multiple goals for South Africa's long term growth as well as yielding benefits for the global community.

Building on this example, leveraging available DIA to support LEDS could help countries move more rapidly from the planning and analysis stages to actual implementation and realization of development and GHG mitigation goals. 


\section{References}

Abrahams, Y.; Fischer, R.; Martin, B.; McDaid, L. (2013). Smart Electricity Planning: Fast-tracking our transition to a healthy, modern, affordable electricity supply for all. The Electricity Governance Initiative of South Africa. Accessed April 2014: https://irp2.files.wordpress.com/2013/05/smartelectricityplanningreport-06052013.pdf.

Austin, G.; Williams, A.; Morris, G.; Spalding-Fecher, R.; Worthington, R. (2003). Employment Potential of Renewable Energy in South Africa. Cape Town, South Africa: Agama Energy. Accessed April 2014: http://www.greentalent.co.za/wpcontent/uploads/2011/04/Agama-Report -EPRESA-Final-Nov-2003.pdf.

Blignaut, J.; Koch, S.; Riekert, J.; Inglesi-Lotz, R.; Nkambule, N. (2011). The External Cost of Coal-fired Power Generation: The case of Kusile. University of Pretoria.

Accessed May 2014:

http://www.greenpeace.org/africa/Global/africa/publications/coal/FULL\%20SCIENTIFIC \%20PAPER\%20139\%20pages.pdf.

Bloomberg. (2015). "South African Rand-US Dollar Exchange Rate (ZAR-USD)." Accessed January 2015: http://www.bloomberg.com/quote/ZARUSD:CUR.

CDM Videos. (2014). CDM Project - 0079 - Kuyasa low-cost urban housing energy upgrade in Cape Town, South Africa. United Nations Climate Change Carbon Mechanisms. Accessed May 2014: https://www.youtube.com/watch?v=b7sN9up-XRs.

Chopra, M.; Lawn, J.; Sanders, D.; Barron, P.; Abdool Karim, S.; Bardshaw, D.; Jewkes, R.; Abdool Karim, Q.; Flisher, A.; Mayosi, B.; Tollman, S.; Churchyard, G.; Coovadia, H. (2009). "Achieving the health Millennium Development Goals for South Africa: challenges and priorities." The Lancet 374 (9694); pp. 1023-1031. Accessed April 2014: http://www.thelancet.com/journals/lancet/article/PIIS0140-6736(09)61122-3/abstract.

"Coal Power." (2015). Eskom. Johannesburg, South Africa: Eskom. Accessed January 2015:

http://www.eskom.co.za/AboutElectricity/ElectricityTechnologies/Pages/Coal Power.aspx.

Cowlin, S.; Cochran, J.; Cox, S.; Davidson, C.; van der Gaast, W. (2012). Broadening the Appeal of Marginal Abatement Cost Curves: Capturing Both Carbon Mitigation and Development Benefits of Clean Energy Technologies. Golden, CO: National Renewable Energy Laboratory. Accessed April 2014: http://www.nrel.gov/docs/fy120sti/54487.pdf.

Edkins, M.; Marquard, A.; Winkler, H. (2010). South Africa's Renewable Energy Policy Roadmaps. Accessed April 2014:

http://www.erc.uct.ac.za/Research/publications/10Edkinesetal-

Renewables roadmaps.pdf.

Gets, A.; Mhlanga, R. (2013). Powering the Future: Renewable Energy Roll-out in South Africa. Greenpeace and Agama Energy. Accessed April 2014:

http://www.greenpeace.org/africa/Global/africa/publications/climate/RenewableEnergyR eport PoweringTheFuture.pdf. 
Gold Standard Foundation. (2014). "About Us." Accessed May 2014:

http://www.goldstandard.org/about-us.

Goldman, Michael. (2010). "Kuyasa CDM Project: Renewable Energy Efficient Technology for the Poor." GIM Case Study No. B070. New York: United Nations Development Programme. Accessed May 2014:

http://www.growinginclusivemarkets.org/media/cases/SouthAfrica Kuyasa 2010.pdf.

IEA. (undated). "International Energy Statistics." Washington, D.C.: IEA. Accessed January 2015:

http://www.eia.gov/cfapps/ipdbproject/iedindex3.cfm?tid=2\&pid=28\&aid=12\&cid=regions \&syid=2008\&eyid=2012\&unit=BKWH.

Integrated Resource Plan for Electricity: 2010 - 2030. (2011). Pretoria, South Africa: South Africa Department of Energy. Accessed April 2014: http://www.energy.gov.za//RP/irp\%20files/IRP2010 2030 Final Report 20110325.pdf.

Integrated Resource Plan. (2014). Pretoria, South Africa: South Africa Department of Energy. Accessed April 2014: http://www.energy.gov.za/files/irp frame.html.

Macknick, J.; Newmark, R.; Heath, G.; Hallett, K. (2011). A Review of Operational Water Consumption and Withdrawal Factors for Electricity Generating Technologies. Golden, CO: National Renewable Energy Laboratory. Accessed April 2014: http://www.nrel.gov/docs/fy110sti/50900.pdf.

Morris, G.; Belton, V. (2011). MCA4Climate, Case Study: Towards a Low-Carbon Fuel Mix in the Electricity Sector in South Africa. Agama Energy and University of Strathclyde. Accessed April 2014:

http://www.mca4climate.info/ assets/files/South Africa Case Final.pdf.

Muller, M. (2012). Lessons from South Africa on the management and development of water resources for inclusive and sustainable growth. Prepared by the Overseas Development Institute (ODI) in partnership with the Deutsches Institut fürEntwicklungspolitik (DIE) and the European Centre for Development Policy Management (ECDPM). Accessed March 2015: http://www.academia.edu/1564589/Lessons from South Africa on the management and development of water resources for inclusive and sustainable growth.

National Climate Change Response White Paper. (undated). South Africa Department of Environmental Affairs. Accessed April 2014:

http://www.sanbi.org/sites/default/files/documents/documents/national-climate-changeresponse-white-paper.pdf.

NPC. (2012). Our future - make it work: National Development Plan - 2030. South Africa National Planning Commission (NPC). Accessed April 2014:

http://www.africaportal.org/sites/default/files/ndp2030 cover overview.pdf. 
Prasad, G.; Bouelle, M.; Boyd, A.; Rahlaos, S.; Wlokas, H.; Yaholnitsky, I. (undated). Energy, Water and Climate Change in Southern Africa. Energy Research Centre, University of Cape Town, South Africa. Accessed April 2014: http://www.idrc.ca/Documents/106298-Energy-exploration-report-Southern-Africa.pdf.

"Presentation on NAMAs" at the Workshop organized by UNFCCC. (2013). Accessed April 2014: https://unfccc.int/files/cooperation support/nama/application/pdf/sth africanamas process.pdf.

"Quick Best Practices Guide to consider Air-related Human Health in your area." (2012). Pretoria, South Africa: Council for Scientific and Industrial Research. Accessed April 2014: http://www.csir.co.za/nre/docs/a4 quickquide medium 1.pdf.

Rutovitz, J. (2010). South African Energy Sector Jobs to 2030. University of Technology - Sydney and Greenpeace. Accessed April 2014: http://uscdn.creamermedia.co.za/assets/articles/attachments/29012 south-african-energysector-jobs-to-2030.pdf.

"Smart Electricity: Planning and building a modern infrastructure for South Africa." (undated.) Electricity Governance Initiative of South Africa. Accessed April 2014: http://www.egi-sa.org.za/smart/introducing-smart-planning/.

Scrieciu, S.S.; Benton, V.; Chalabi, Z.; Mechler, R.; Puig, D. (2014). “Advancing methodological thinking and practice for development-compatible climate policy planning." Mitigation and Adaptation Strategies for Global Change (19); pp. 261-288.

Spalding-Fecher, R.; Matibe, D. (2003). "Electricity and Externalities in South Africa." Energy Policy (31); pp. 721-734. Accessed April 2014:

http://www.sciencedirect.com/science/article/pii/S0301421502001234.

Steele, M.; Shulz, N. (2012). Water Hungry Coal. Greenpeace Africa. Accessed April 2014:

http://www.greenpeace.org/africa/Global/africa/publications/coal/WaterHungryCoal.pdf.

UNFCCC. (2010). CDM Project Co-benefits in Cape Town, South Africa. United Nations Framework Convention on Climate Change.

http://cdm.unfccc.int/about/ccb/CDM Cobenefits Kuyasa SouthAfrica.pdf

UNFCCC (2014). "Compendium on methods and tools to evaluate impacts of, and vulnerability and adaptation to, climate change." Accessed October 30, 2014:

http://unfccc.int/adaptation/nairobi work programme/knowledge resources and public ations/items/5440.php.

"Project 0079: Kuyasa low-cost urban housing energy upgrade project, Khayelitsha (Cape Town; South Africa)." (undated).From http://cdm.unfccc.int/. Accessed January 7, 2015: http://cdm.unfccc.int/Projects/DB/DNV-CUK1121165382.34/view. 
The True Cost of Coal in South Africa - Paying the price of coal addiction. (undated). Greenpeace. Accessed May 2014:

http://www.greenpeace.org/africa/Global/africa/publications/coal/TrueCostOfCoal.pdf.

The Water Project. (2014). "Water in Crisis: South Africa." Accessed April 2014:

http://thewaterproject.org/water-in-crisis-south-africa.php.

Wassung, N. (2010). Water Scarcity and Electricity Generation in South Africa. Thesis. Stellenbosch, South Africa: University of Stellenbosch. Accessed April 2014:

http://hdl.handle.net/10019.1/18158.

White Paper on Renewable Energy. (2003). Department of Minerals and Energy, Republic of South Africa. Accessed April 2014:

http://www.energy.gov.za/files/policies/whitepaper renewables 2003.pdf.

Winkler, H. (ed.) (2007). Long Term Mitigation Scenarios, Technical Report. Pretoria, South Africa: Energy Research Center (ERC). Accessed April 2014:

http://dspace.cigilibrary.org/ispui/bitstream/123456789/33713/1/07-Winkler-LTMSTechnical\%20Report.pdf?1. 


\section{Appendix A. Illustrative Example of Analysis Integration to Support Prioritization of Low Carbon Development Actions}

As described in this report, a number of studies have analyzed various development impacts associated with energy technologies in South Africa. While these analyses are each useful alone, they could also be integrated to provide a broader picture of development impacts of these technologies. The GoSA's LTMS and NCCRS provide a framework to link national development priorities, particularly employment, with proposed climate mitigation actions, but it is unclear how the impact studies and national climate change plans have influenced decision making in South Africa. Cowlin et al. (2012) developed a prioritization framework that builds on a marginal abatement cost curve to also present development impacts of low carbon actions. Such an integrated picture could support prioritization and inform choice of energy sector actions to support low carbon development. This framework is presented below in Figure A-1 and adapted for the South African context later in this section.

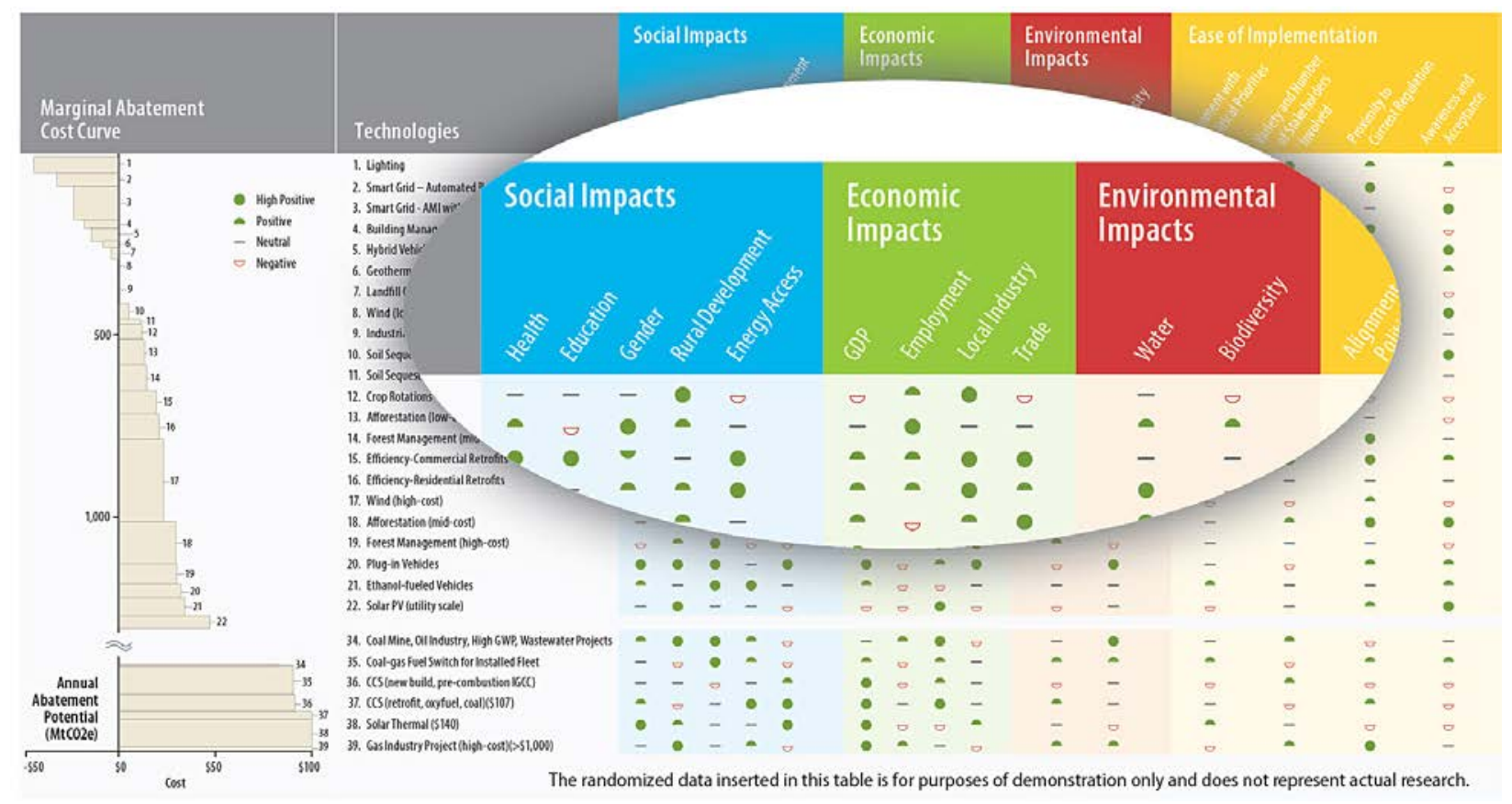

Figure A-1. Sample DIA framework 
In Figure A-2, this framework is adapted to provide a simple illustrative example of how available analysis outputs can be integrated to inform prioritization of low carbon development actions. This example looks at one category of technologies (energy) ${ }^{13}$ and three types of impacts (employment, water use, and health); however, this analysis could be expanded to compare a broader range of technologies across multiple sectors and could consider an expanded set of impacts. The framework supports evaluation of technology options in terms of development priorities such as employment, health, energy access, and/or other key national development objectives. In the context of South Africa and for this illustration, technologies were chosen in relation to select NCCRS and LTMS priority actions and impacts were chosen in relation to South Africa's development priorities and availability of analyses for the respective technologies.

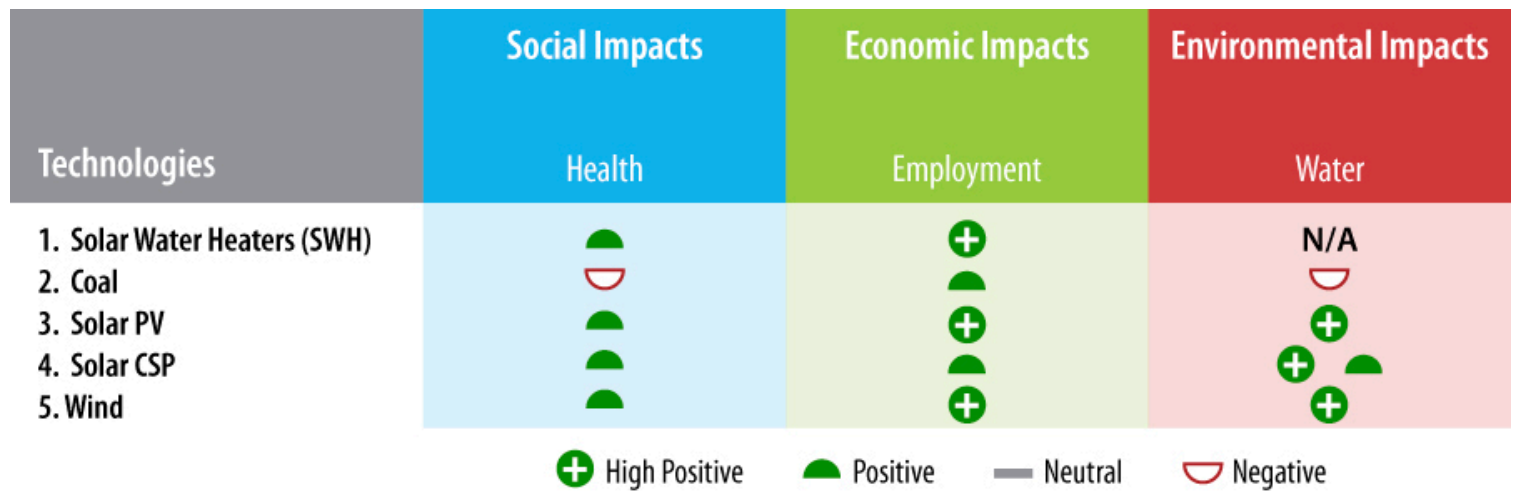

Figure A-2. Illustrative example of integrated DIA prioritization framework drawing from analysis presented in this case study 14

* Note Solar CSP water impacts depend on the CSP technology used.

In practice, this type of integrated framework could be used to support consultative stakeholder processes to prioritize low carbon development actions. Experts that prepared each of the analyses could be engaged with this process to discuss assumptions of the analysis, data inputs, methods, and findings. Stakeholders could then use this information as a starting point for broader discussions on local circumstances and to validate the assessments. This type of process might also include an exercise to weight different impacts in relation to their importance to the country and linkages to broader development goals. ${ }^{15}$ This example provides just one approach for integrating analysis that is already available to support stakeholder-led prioritization of low carbon development actions.

A key first step is to establish a standardized scoring scheme to support unbiased analysis and consistent results. An example scoring scheme for comparing the development benefits of using clean energy technologies to displace coal power, using the data compiled for this case study, is presented in Table 9. In many cases, quantitative data that can be clearly tied to national development goals and that are

\footnotetext{
${ }^{13}$ The framework does not consider all energy technologies, but focuses on technologies considered in the analyses in this case study.

14 This example prioritization framework is not presented as a comprehensive analysis of all relevant factors, but is presented to illustrate an approach to illuminate the links between development options and energy.

${ }^{15}$ Weighting of impacts was not used for the visual in Figure A-1, but could be considered by countries as a way to further align the analysis with broader development goals.
} 
similar to the health impacts identified in this case study are not available. Limiting scoring to three choices (positive, negative, or neutral), instead of four, simplifies the process and has been applied successfully in other countries.

Table A-1. Scoring Scheme for Assessing Development Benefits of Clean Energy Technologies

\begin{tabular}{|c|c|c|c|c|}
\hline \multirow{2}{*}{$\begin{array}{c}\text { National } \\
\text { Development } \\
\text { Priority }\end{array}$} & \multirow{2}{*}{$\begin{array}{c}\text { Unit of } \\
\text { Measurement }\end{array}$} & \multicolumn{2}{|c|}{ Scoring } & \multirow{2}{*}{$\begin{array}{c}\text { Data Source for } \\
\text { Prioritization } \\
\text { Framework }\end{array}$} \\
\hline & & Positive & High Positive & \\
\hline Employment & $\begin{array}{l}\text { Gross jobs per } \\
\text { MW (construction } \\
\text { and O\&M phases) }\end{array}$ & $1-15$ & $16-31$ & $\begin{array}{l}\text { ERC } 2010 \\
\text { (Table } 4 \text { in this } \\
\text { document) }\end{array}$ \\
\hline Water use & $\begin{array}{l}\text { Gallons of water } \\
\text { saved/MWh from } \\
\text { coal power } \\
\text { substitution }\end{array}$ & $26-439$ & $>439$ & $\begin{array}{l}\text { Wassung (Table } \\
8 \text { in this } \\
\text { document) }\end{array}$ \\
\hline Health & $\begin{array}{l}\text { Qualitative } \\
\text { improvement in } \\
\text { health from coal } \\
\text { power substitution }\end{array}$ & $\begin{array}{l}\text { - Technologies that can } \\
\text { offset coal power } \\
\text { production are } \\
\text { assumed to have a } \\
\text { positive impact on } \\
\text { health } \\
\text { - SWHs are assumed } \\
\text { to have a positive } \\
\text { impact on health }\end{array}$ & $\begin{array}{l}\text { NOTE: To err on the } \\
\text { conservative side, qualitative } \\
\text { health impacts were scored } \\
\text { positive, rather than high } \\
\text { positive, as further analysis of } \\
\text { the literature would be needed } \\
\text { to make the distinction between } \\
\text { positive and high positive. }\end{array}$ & $\begin{array}{l}\text { Spalding-Fecher } \\
\text { and Matibe } 2003 \\
\text { and "Impact and } \\
\text { Validation" } 2014\end{array}$ \\
\hline
\end{tabular}

The example scoring scheme is used to create the DIA framework in Figure A-2, a format that quickly conveys the conclusion that solar PV and wind both provide highly positive employment and water savings as well as positive health impacts (relative to coal). An advantage of the framework is that it is transparent, and is backed by studies and analyses conducted to date. Additional impacts of priority interest to stakeholders and government decision makers - such as energy access, biodiversity, balance of payments, and GHG emissions-can be added to the framework.

As previously noted, the framework simply provides a way of gathering and presenting information in a very systematic and transparent way. However, the framework is a tool, not a definitive assessment, and ideally should be updated as new data and information are available. This illustrative example is meant to demonstrate that available analyses can inform stakeholder-led prioritization processes to inform LEDS action and communication of benefits to stakeholders. The engagement of stakeholders cannot be underestimated, as their expertise and knowledge of local circumstances is a crucial input for these types of processes. In the case of South Africa, the framework could be expanded through inclusion of additional impact analysis studies related to LEDS actions, and in some cases, through improving studies with further data collection and/or undertaking new and more robust analysis. Workshops and consultative processes could also complement and further inform development of the framework (e.g., through expert and stakeholder input) and provide forums to present findings to policymakers and broader stakeholder groups, with a goal of informing LEDS policy and building public support for LEDS action. 
DIA can be a powerful tool to support low carbon development planning processes and action implementation. However, the complexity associated with comparing multiple technologies across various impacts requires significant analytical effort. Integrating available analytical outputs (whether they were produced in the context of a LEDS process or not) under one overarching framework can be an efficient approach for utilizing available information, engaging stakeholders, and improving the robustness of development-focused prioritization. 


\section{Appendix B. Summary Table of DIA Studies and Tools}

Table B-1 below summarizes DIA studies, methods, and tools described in this report.

Table B-1. DIA Studies and Tools

\begin{tabular}{|c|c|c|c|}
\hline Impact & Study & Methods/Tools Used & Link \\
\hline \multirow[t]{4}{*}{ Multiple } & LTMS & $\begin{array}{l}\text { MARKet ALlocation (MARKAL) } \\
\text { model, Input-Output (I-O)/Social } \\
\text { Accounting Matrix (SAM) multipliers, } \\
\text { and Computable General } \\
\text { Equilibrium (CGE) }\end{array}$ & $\begin{array}{l}\frac{\text { http://dspace.cigilibrary.org/isp }}{\text { ui/bitstream/123456789/33713 }} \\
\text { 11/07-Winkler-LTMS- } \\
\text { Technical\%20Report.pdf?1 }\end{array}$ \\
\hline & NCCRS & $\begin{array}{l}\text { Carbon budget approach and } \\
\text { National Employment Vulnerability } \\
\text { Assessment (proposed) }\end{array}$ & $\begin{array}{l}\text { http://www.climateresponse.c } \\
\text { o.za/home/gp/5.4 }\end{array}$ \\
\hline & IRP & $\begin{array}{l}\text { Least cost optimization model and } \\
\text { "qualitative balancing" }\end{array}$ & $\begin{array}{l}\text { http://www.energy.gov.za/IRP/ } \\
\text { irp\%20files/IRP2010 2030 Fi } \\
\text { nal Report 20110325.pdf }\end{array}$ \\
\hline & $\begin{array}{l}\text { MCA4Climate } \\
\text { South Africa Case } \\
\text { Study }\end{array}$ & $\begin{array}{l}\text { MCA4Climate analytical framework } \\
\text { and modeling tools }\end{array}$ & $\begin{array}{l}\text { http://www.mca4climate.info/ } \\
\text { assets/files/South Africa Cas } \\
\underline{\text { e Final.pdf }}\end{array}$ \\
\hline \multirow[t]{3}{*}{ Employment } & $\begin{array}{l}\text { South African } \\
\text { Energy Sector Jobs } \\
\text { to } 2030\end{array}$ & $\begin{array}{l}\text { Electricity consumption projections } \\
\text { and job multipliers }\end{array}$ & $\begin{array}{l}\text { http://us- } \\
\text { cdn.creamermedia.co.za/asse } \\
\frac{\text { ts/articles/attachments/29012 }}{\text { south-african-energy-sector- }} \\
\text { jobs-to-2030.pdf }\end{array}$ \\
\hline & $\begin{array}{l}\text { South Africa's } \\
\text { Renewable Energy } \\
\text { Policy Roadmaps } \\
\end{array}$ & $\begin{array}{l}\text { Literature (estimation of job } \\
\text { potential based on previous } \\
\text { research) and SNAPP Tool }\end{array}$ & $\begin{array}{l}\text { http://www.erc.uct.ac.za/Rese } \\
\text { arch/publications/10Edkineset } \\
\text { al-Renewables roadmaps.pdf } \\
\end{array}$ \\
\hline & $\begin{array}{l}\text { Electricity } \\
\text { Governance } \\
\text { Initiative (EGI) }\end{array}$ & SNAPP spreadsheet tool & $\begin{array}{l}\text { http://irp2.files.wordpress.com } \\
\text { I2013/05/smartelectricityplanni } \\
\underline{\text { ngreport-06052013.pdf }}\end{array}$ \\
\hline \multirow[t]{4}{*}{ Water use } & $\begin{array}{l}\text { Energy, Water, and } \\
\text { Climate Change in } \\
\text { Southern Africa }\end{array}$ & $\begin{array}{l}\text { Previous literature on electricity } \\
\text { technology water consumption - } \\
\text { Macknick, } 2011\end{array}$ & $\frac{\text { http://www.idrc.ca/Documents/ }}{\text { 106298-Energy-exploration- }}$ \\
\hline & $\begin{array}{l}\text { A Review of } \\
\text { Operational Water } \\
\text { Consumption and } \\
\text { Withdrawal Factors } \\
\text { for Electricity } \\
\text { Generating } \\
\text { Technologies }\end{array}$ & $\begin{array}{l}\text { Assessed water consumption and } \\
\text { withdrawal for the operational phase } \\
\text { of electricity generating } \\
\text { technologies using data for power } \\
\text { plants in the United States collected } \\
\text { by the EIA, USGS, State Utilities, } \\
\text { and a number of other international } \\
\text { sources (listed in the references } \\
\text { section) }\end{array}$ & $\begin{array}{l}\text { http://www.nrel.gov/docs/fy11 } \\
\text { osti/50900.pdf }\end{array}$ \\
\hline & $\begin{array}{l}\text { Water Scarcity and } \\
\text { Electricity } \\
\text { Generation in } \\
\text { South Africa }\end{array}$ & $\begin{array}{l}\text { Technology specific water factors to } \\
\text { estimate water savings from coal } \\
\text { replacement }\end{array}$ & \\
\hline & Water Hungry Coal & $\begin{array}{l}\text { Technology specific factors to } \\
\text { estimate water savings from coal } \\
\text { replacement }\end{array}$ & $\begin{array}{l}\text { http://www.greenpeace.org/afr } \\
\text { ica/Global/africa/publications/c } \\
\text { oal/WaterHungryCoal.pdf }\end{array}$ \\
\hline \multirow[t]{2}{*}{ Health } & $\begin{array}{l}\text { Electricity and } \\
\text { Externalities in } \\
\text { South Africa }\end{array}$ & $\begin{array}{l}\text { EXMOD impact pathway model for } \\
\text { assessing links between emissions } \\
\text { and human health }\end{array}$ & $\begin{array}{l}\text { http://www.sciencedirect.com/ } \\
\text { science/article/pii/S03014215 } \\
\underline{02001234}\end{array}$ \\
\hline & $\begin{array}{l}\text { Kuyasa CDM } \\
\text { Project - Impact } \\
\text { and Validation }\end{array}$ & $\begin{array}{l}\text { Baseline survey followed by an } \\
\text { impact survey }\end{array}$ & $\begin{array}{l}\text { http://www.carbonprogramme } \\
\text { s.co.za/projects-kuyasa.php }\end{array}$ \\
\hline
\end{tabular}

